DOI https://doi.org/10.30525/978-9934-26-114-5-25

\title{
ЕКОНОМІЧНЕ ВИХОВАННЯ В ОСВІТНЬОМУ ПРОЦЕСІ ПОЧАТКОВОЇ ШКОЛИ
}

\author{
Фатич М. М. \\ аспірант кафедри теорї і методики виховання \\ Київський національний педагогічний університет \\ імені М. П. Драгоманова \\ м. Київ, Україна
}

У зв'язку з корінними змінами економічного характеру в сучасному суспільстві виникла об'єктивна потреба в організації економічної освіти, починаючи 3 молодших класів загальноосвітньої школи. Час вимагає суттєвого удосконалення змісту навчально-виховного процесу, створення відповідних педагогічних умов для економічного виховання молодших школярів. За останні роки можна спостерігати зростання рівня інтересу науковців, педагогів, методистів 3 вирішення проблем економічного виховання на основі безперервності процесу освіти. Культурологічна, соціальна дійсність вимагає від кожного 3 нас відповідного ставлення до економічної ситуації у державі.

Дослідниця Н. Пасічник розглядає «економічне виховання як частину навчально-виховного процесу, спрямовану на розв'язання загальних завдань виховання і одну із сполучних ланок між розумовим, моральним, трудовим та іншими компонентами виховання [5, с. 51-52].

Академік В. Синьов зауважив, що «економічне виховання $\epsilon$ невід'ємним компонентом підготовки до трудової діяльності учнів та передбачає: безпосередню участь людини у виробничих відносинах; формування життєвих уявлень про ринкову економіку; виховання якостей дбайливих хазяїв, ощадливого ставлення до матеріальних цінностей, природи, майна, бережливості у використанні енергетичних джерел, продуктів харчування тощо» [7].

Аналіз літератури дозволяє стверджувати, що «економічне виховання - це організована педагогічна діяльність, спрямована на формування економічної свідомості учнів. Економічна свідомість забезпечує розуміння економічного життя суспільства, перетворення кожного працівника в активного творчого учасника виробничого процесу. В умовах економічних реформ формування економічної свідомості підростаючого покоління стає загальним і обов'язковим» [8].

Що стосується завдань економічного виховання, то «частіше виокремлюють такі: 
a) ознайомлення учнів із законами ринкової економіки, перебудовою структури виробництва, підвищенням його ефективності, вдосконаленням виробничих відносин, системою управління і методами управління;

б) формування здатності до економічного мислення, творчого пошуку підвищення продуктивності праці, вміння швидко оволодівати новими формами і методами праці;

в) виховання почуття рис господаря, що працює 3 віддачею, бережливо ставиться до результатів праці;

г) виховання здорових матеріальних потреб, уміння розпоряджатися зарплатою [4].

Для того аби вирішити дані завдання потрібно проаналізувати базу яка існує аби впроваджувати економічну освіту яка відповідно не проходить без економічного виховання. Початкова економічна освіта трактується як своєрідний крок соціалізації молодшого школяра, який може зрозуміти основні поняття, уміння економічної діяльності. Як зазначає К. Байчакова, «метою початкової економічної освіти $\epsilon$ формування у молодшого школяра економічної культури, початкових уявлень про оточуючі економічні умови життя і діяльності людей. Школяр повинен мати уявлення про шкільну економіку...» [1].

Конкретний зміст інновацій ідеї економічної освіти, нових навчальних програм, підручників і навчальних посібників, мають відображати вимоги державних освітніх стандартів. Пропонуємо короткий аналіз деяких програм «Основи економічних знань для молодших школярів», розроблена колективом СЕПШ при ХГІ «НУА» на чолі з О. Божко. Метою цієї програми є формування економічного мислення і виховання культури поведінки в умовах ринкового суспільства. Досягти цього, на думку авторів, можна вивчаючи такі економічні концепції, як економіка, потреби і блага, економічні ресурси, обмеженість і проблема вибору, альтернативні вартість та витрати, спеціалізація, обмін, гроші, натуральне й товарне господарство. Провідна роль відводиться активним методам навчання.

«Експериментальна програма 3 економіки для учнів $1-12$ класів», розроблена П. Власенко, М. Гуринок, І. Дорогопулько. Основний принцип побудови програми - безперервність і послідовність засвоєння економічних категорій, таких як потреби, їх різноманіття, економіка в школі, ресурси, обмін, гроші. Особлива увага у програмі приділяється питанням виробництва як основи економіки, та праці як основного економічного ресурсу [2, с. 118-119].

«Економіка для молодших школярів» розроблена Т. Гільберг відповідно до концепції особистісно орієнтованого підходу до навчання на основі вимог Державного стандарту з економіки й призначена для 102 
учнів 3-4 класів загальноосвітніх навчальних закладів. Окрім зазначених у попередніх програмах економічних концепціях, автор пропонує вивчати у початковій школі питання торгівлі, сімейного господарства, бюджету сім'ї, державних витрат (пенсій, стипендій).

«Початки економіки», автором якої є О. Варецька, передбачає вивчення загальних економічних явищ, у тому числі реальних проблем розвитку економіки, іiі майбутніх потреб і врахування аспекту духовності. Економічні концепції підібрані відповідно до невеликого життєвого досвіду, розумових здібностей дітей молодшого шкільного віку, які можуть бути застосовані у їх житті, а також сприяють засвоєнню учнями реального мінімального обсягу знань. Це, зокрема, такі поняття, як ринок, потреби, блага, попит, гроші, валюта, заробітна плата, банк, грошова система тощо [3, с.7].

Порівняльний аналіз зазначених програм показав наступне:

- усі автори доводять необхідність введення економіки у навчально- виховний процес початкової школи;

- усі програми передбачають міжпредметні зв'язки 3 іншими курсами;

- розробники програм вважають, що основні економічні знання та вміння у молодших школярів можна сформувати при вивченні таких економічних концепцій, як потреби, їх різновиди, ресурси та їх класифікація, товари і послуги, обмін, спеціалізація, поділ праці, гроші, їх властивості та функції.

Навчальні програми «Азбука споживача», «Основи споживчих знань», «Цікава економіка» $\epsilon$ програмами початкової економічної освіти в умовах формування ринкової економіки 3 практичним напрямком для учнів початкової школи. «Азбука споживача» - це навчальний курс за вибором, розрахований на два роки. Курс «Основи споживчих знань» розрахований на вивчення впродовж 4-х років у початкових класах. Мета зазначених курсів - сприяти формуванню в учнів культури споживача, необхідної для якісного та безпечного споживання, яке базується на засвоєнні прав споживача, визнаних світовою спільнотою та законодавством України.

Мета курсу «Цікава економіка» - сприяти формуванню в учнів потреби до пізнання світу і людини в ньому як біологічної та соціальної істоти; формування економічного мислення та виховання культури поведінки в умовах ринкового суспільства; засвоєння духовних цінностей в різноманітних сферах: комунікативної, пізнавальної, екологічної, моральної, діяльнісної, вольової, емоційної, естетичної [6].

Економічна освіта накладає відбиток на загальний світогляд людини, що впливає на його культурний рівень, сприяє виробленню адекватних уявлень про дійсність, яка оточує. Вивчення економіки 
допомагає учням отримати більш повне уявлення про формування й розвиток суспільства, дає їм змогу сформувати цілісну картину навколишнього світу, визначити свою життєву позицію.

\title{
Література:
}

1. Байкачова К. В. Сучасний стан та проблеми економічної освіти молодших школярів. URL: http://molodyvcheny.in.ua/files/journal/ 2018/12.1/18.pdf.

2. Божко О. Програма 3 курсу «Основи економічних знань». Початкова освіта. 2003. № 31 (223). С. 2-3.

3. Варецька О. В. Програма курсу за вибором з економіки «Початки економіки» для початкової школи загальноосвітніх навчальних закладів. Запоріжжя: Просвіта, 2008. 28 с.

4. Кулішов В. В. Методичні засади формування економічної компетентності у процесі підготовки фахівців технологій: монографія. К.: Каравела, 2011. 567 с.

5. Пасічник Н. О. Формування економічної культури школярів як умова розвитку цивілізованих ринкових відносин. Рідна школа. 2007. № 4. C. 45-47.

6. Сасова I. А. Економічна підготовка учнів шкіл : навчальний посібник. Київ, 2000. 87 с.

7. Сигида С.В. Уроки економіки у початковій школі. Економіка. 2005. № 2. C. 21-22.

8. Слободянюк Н. Г. Основи економічних знань у початкових класах. Початкова школа. 2003. № 11. С. 20-21.

DOI https://doi.org/10.30525/978-9934-26-114-5-26

\section{СИСТЕМА ВИЩОЇ ЕКОНОМІЧНОЇ ОСВІТИ В УРСР У ДРУГІЙ ПОЛОВИНІ ХХ СТОЛІТТЯ}

\author{
Федун Д. С. \\ аспірант кафедри психології, педагогіки та філософії \\ Кременчуиький національний університет \\ імені Михайла Остроградського \\ м. Кременчук, Україна
}

Необхідність вивчення системи підготовки економічних кадрів в Україні, в період 3 плановою системою економіки, обумовлена все більше зростаючою сьогодні необхідністю підготовки фахівців, які 